TAPROBANICA, ISSN 1800-427X. June, 2014. Vol. 06, No. 01: pp. 53-54.

(C) Research Center for Climate Change, University of Indonesia, Depok, Indonesia \& Taprobanica Private Limited, Homagama, Sri Lanka http://www.sljol.info/index.php/tapro

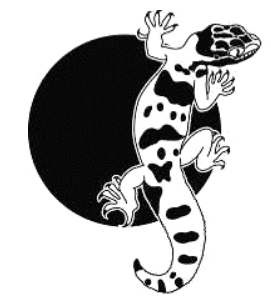

\section{First confirmed record of Calodactylodes aureus (Reptilia) from Karnataka, India}

The Indian Golden Gecko Calodactylodes aureus (Beddome, 1870) was known originally from the Tirupati hills in the Seshachalam range (Beddome, 1870; Smith, 1935; Daniel \& Bhushan, 1985; Bauer \& Günther, 1991) and the Velikonda range (Daniel et al., 1986). It is listed under Schedule I of the Indian Wildlife Protection Act (1972) as it was considered rare, being found at the time only in the Seshachalam range. Subsequently, researchers have revealed the presence of this species from the Papikonda Hills (Perantalapally) in Khammam District, Maredumilli in East Godavari District, Araku Valley and Ananthagiri Hills in Vishakhapatnam District (Javed et al., 2007, Sreekar et al., 2010, Chettri \& Bhupathy, 2011) and Kadapa Hills (Guptha et al., 2012) from Andhra Pradesh, Niyamgiri hill ranges of Rayagada, Kalahandi Districts in Odhisha (Dutta et al., 2005) and Vellore and Balmathi Hill, Tamil Nadu (Bauer \& Das, 2000; Rajasekhar \& Nandakumar, 2007). Furthermore, this species was recently reported from Sathgar Hill, Kailasagiri Hill (Ambur) and Valli Malai in Vellore District, Sayed Basha Malai in Krishnagiri District, Nedumkunam Hill, Melthiruvadathanur (Morambu), Karadi Parai and Sathanur Dam in Tiruvanamalai District and the Gingee Hills in Villupuram District of Tamil Nadu (Kalaimani \& Nath, 2012, 2013). Reddy et al. (2013) reported the occurrence of this species from Nigidi reserve forest area in the Anantapur District of Andhra Pradesh and this is the westernmost locality record of this species to date.

Bauer \& Das (2000) mention the observation of a species similar to $C$. aureus from Castle Rock, in the Western Ghats of Karnataka but no specimens were collected and hence the identity of the species is not yet confirmed with confidence. Other than this doubtful record, this species has not so far been sighted or reported from Karnataka, India and through this paper we give the first confirmed record of the Indian Golden Gecko Calodactylodes aureus from Karnataka.

While studying bats in the south-eastern parts of Karnataka in November 2013, we surveyed many sites in Kolar, Tumkur and Bellary Districts in Karnataka. Hampi $\left(15^{\circ} 20^{\prime} \mathrm{N}\right.$ $\left.76^{\circ} 28^{\prime} \mathrm{E}\right)$, located in Bellary District, Karnataka, is an UNESCO World Heritage Site flanked on one side by the river Tungabhadra and on the other side by vast stretches of boulder hills. At this site, we found many rocky caves and crevices among large rocky boulders. In two such crevices at an altitude of $439 \mathrm{~m}$ asl located about $600 \mathrm{~m}$ away from the river, we encountered a few individuals of Indian Golden Gecko at a height of approximately $1.21-1.52 \mathrm{~m}$ above ground level. We photographed the geckos to confirm identification and owing to their large size, large-sized eyes, characteristically-shaped adhesion pads of the pes and manus and golden colouration, we confirmed them as the Indian Golden Gecko. We did not observe any egg clusters at this site. Further searches in the vicinity yielded no other sightings and we feel that the population may be using inaccessible crevices located at a greater height above ground level in the location. The temperature inside the crevices where the geckos were found was lower than on the outside rock surface. As with Reddy et al. (2013), the present observation of the Indian Golden Gecko is contrary to the observations of Sreekar et al. (2010) and Kalaimani \& Nath (2013) who reported that the species lives in close proximity to a water source, and substantiates that the species can also be found in drier areas as has been opined by Bauer \& Das (2000). The presence of the Indian Golden Gecko Calodactylodes aureus in Hampi, Karnataka is in concurrence to a preliminary species distribution modelling study conducted by us to understand the distribution of this species and signifies the distribution extent may 
be larger than is currently known, and further research is needed to ascertain its true distribution extent.

\section{Acknowledgements}

The authors thank the Principal Chief Conservator of Forests, Karnataka Forest Department for the study permission, the DFO Bellary District for the cooperation extended during the survey, the Head, Department of Zoology, Osmania University for necessary facilities. CS and BS thank DBT, Govt. of India and CS, TAS and GD thank DST-SERB, Govt. of India for research grants; HK thanks UGC, Govt. of India for research fellowship.

\section{Literature Cited}

Bauer, A. M. and R. Günther, 1991. An annotated type catalogue of the geckos (Reptilia: Gekkonidae) in the Zoological Museum, Berlin. Mitteilungen aus dem Zoologischen Museum Berlin, 67: 279-310.

Bauer, A. M. and I. Das, 2000. A review of the gekkonid genus Calodactylodes (Reptilia: Squamata) from India and Sri Lanka. Journal of South Asian Natural History, 5 (1): 25-35.

Beddome, R. H., 1870. Descriptions of some new lizards from the Madras Presidency. Madras Monthly Journal of Medical Science, 1: 30-35.

Chettri, B. and S. Bhupathy, 2010. Three little known reptile species from the Araku Valley, Eastern Ghats with notes on their distribution. Journal of Threatened Taxa, 2 (8): 1109-1113.

Daniel, J. C. and B. Bhushan, 1985. The golden gecko of Tirumalai Hills. Hornbill, 3 (3): 17-18.

Daniel, J. C., B. Bhushan, and A. G. Sekar, 1986. Rediscovery of the golden gecko Calodactylodes aureus (Beddome) in the Eastern Ghats of Andhra Pradesh. Journal of Bombay Natural History Society, 83: 15-16.

Dutta, S. K., B. Mohanty, and P. P. Mohapatra, 2005. Niyamgiri unraveled. Sanctuary Asia Magazine, October: 56-59.

Guptha, M. B., P. V. C. Rao, N. V. S. Prasad, S. R. S. C. S. Maddala, P. M. Babu, and D. S. Reddy, 2012. Status of Herpetofauna in Seshachalam Biosphere Reserve, Eastern Ghats, Andhra Pradesh, India. World Journal of Zoology, 7 (2): 131-134.
Javed, S. M. M., A. Waran and F. Tampal, 2007. On the occurrence of Golden Gecko Calodactylodes aureus in Papikonda Hills, Eastern Ghats, India. Zoo's Print Journal, 22 (6): 2727-2729.

Kalaimani A. and A. Nath, 2012. A new locality and microhabitat usage by Calodactylodes aureus (Beddome, 1870) from Tamil Nadu, Eastern Ghats, Southern India. Herpetotropicos, 8 (1-2): 49-54.

Kalaimani A. and A. Nath, 2013. The Indian Golden Gecko, Calodactylodes aureus (Beddome, 1870) in Tamil Nadu, India. Taprobanica, 5 (1): 81-84.

Rajshekhar, M. and N. V. Nanda Kumar, 2007. A new finding on the occurrence of golden gecko (Calodactylodes aureus) in the rock boulders near Vellore town. The Bioscan, 2 (1): 61-62.

Reddy, Y. A., P. Indira, T. Pullaiah, B. Sadasivaiah, K. R. K. Swamy, and S. S. Rani, 2013. Range extension of Indian Golden Gecko Calodactylodes aureus in Andhra Pradesh, India. Reptile Rap, 15: 41-42.

Smith, M. A., 1935. The fauna of British India, including Ceylon and Burma. Reptilia and Amphibia, vol. 2: Sauria. Taylor and Francis, London: 440.

Sreekar, R., C. Srinivasulu, M. Seetharamaraju, and C. A. Srinivasulu, 2010. Selection of egg attachment sites by the Indian Golden Gecko Calodactylodes aureus (Beddome, 1870) (Reptilia: Gekkonidae) in Andhra Pradesh, India. Journal of Threatened Taxa, 2 (11): 1268-1272.

Submitted: 11 Jan. 2014, Accepted: 18 March 2014 Section Editor: John Rudge

$$
\begin{aligned}
& \text { B. Srinivasulu }{ }^{1-4}, \text { C. Srinivasulu } \\
& \text { Shah }^{1,2}, \text { T. A. Devender }
\end{aligned}
$$

${ }^{1}$ Natural History Museum and Wildlife Biology and Taxonomy Lab, Department of Zoology, University College of Science, Osmania University, Hyderabad 500007, India

${ }^{2}$ Zoo Outreach Organization, 96, Kumudham Nagar, Vilankurichi Road, Coimbatore 641035, Tamil Nadu, India ${ }^{3}$ Biodiversity Research and Conservation Society, G4, MRK Towers, Swarnadhamanagar, Old Bowenpally, Secunderabad 500011, India ${ }^{4}$ E-mail: bharisrini@gmail.com 